\title{
Photosynthetic Responses of Creeping Bentgrass to Reduced Root-zone Temperatures at Supraoptimal Air Temperature
}

\author{
Qingzhang Xu, ${ }^{1}$ Bingru Huang, ${ }^{2}$ and Zhaolong Wang ${ }^{1}$ \\ Department of Plant Science, Rutgers University, New Brunswick, NJ 08901
}

\begin{abstract}
AdDitional INDEX wORDs. Agrostis stolonifera, heat stress, photosynthesis, chlorophyll content, photochemical efficiency, Rubisco

ABSTRACT. High air and soil temperatures are major factors limiting growth of cool-season grasses. A previous study by the authors reported that a soil temperature reduction of only $3{ }^{\circ} \mathrm{C}$ when air temperature was maintained at $35{ }^{\circ} \mathrm{C}$ significantly improved shoot and root growth of creeping bentgrass [Agrostis stolonifera L. var. palustris (Huds.) Farw. (syn. A. palustris Huds.)]. This study was designed to investigate the responses of photosynthetic activities of creeping bentgrass to lowered root-zone temperatures from the supraoptimal level when shoots were exposed to high air temperature. Two cultivars of creeping bentgrass, 'L-93' and 'Penncross', were exposed to the following air/root-zone temperature regimes in growth chambers and water baths: 1$)$ optimal air and soil temperatures $\left(20 / 20^{\circ} \mathrm{C}\right.$, control); 2$)$ lowering soil temperature by 3,6 , and $11^{\circ} \mathrm{C}$ from $35^{\circ} \mathrm{C}$ at high air temperatures $\left(35 / 32,35 / 29\right.$, and $\left.35 / 24^{\circ} \mathrm{C}\right)$; and 3$)$ high air and soil temperatures $\left(35 / 35^{\circ} \mathrm{C}\right)$. Soil temperature was reduced from $35^{\circ} \mathrm{C}$ by circulating cool water $\left(18^{\circ} \mathrm{C}\right)$ in water baths at variable flow rates. Both cultivars had similar responses to high or low root-zone temperatures with high air temperature. High air and root-zone temperatures caused significant reductions in canopy photosynthetic rate $\left(\mathbf{P}_{\text {canopy }}\right)$, single-leaf photosynthetic rate $\left(P_{\text {leaf }}\right)$, leaf chlorophyll content, photochemical efficiency (Fv/Fm), and ribulose-1,5bisphosphate carboxylase/oxygenase (Rubisco) activity, beginning on day 1 of high air and soil temperature stress for $P_{\text {canopy }}$ and $P_{\text {leaf }}$, and day 7 for chlorophyll content, $\mathrm{Fv} / \mathrm{Fm}$, and Rubisco activity. The $3{ }^{\circ} \mathrm{C}$ reduction in root-zone temperature at high air temperature had no effect on those photosynthetic parameters, except chlorophyll content. Reducing root-zone temperature by $6^{\circ} \mathrm{C}$ or $11^{\circ} \mathrm{C}$ while maintaining air temperature at $35^{\circ} \mathrm{C}$ significantly improved $P_{\text {canopy }}, P_{\text {leaf }}$, leaf chlorophyll content, $F v / F m$, and Rubisco activity. Single leaf photosynthetic rate at $35 / 24{ }^{\circ} \mathrm{C}$ was not different from the control level, but $P_{\text {canopy }}$ at $35 / 24{ }^{\circ} \mathrm{C}$ was lower than the control level. A reduction in root-zone temperature enhanced canopy and single-leaf photosynthetic capacity even though shoots were exposed to supraoptimal air temperature, which could contribute to improved turfgrass growth.
\end{abstract}

In warm climate areas, root-zone temperatures often reach injuriously high levels and adversely affect shoot growth and survival of cool-season plants (Paulsen, 1994). Root-zone temperature is more critical than air temperature in controlling plant growth (Kuryanagi and Paulsen, 1988; Xu and Huang, 2000a, 2000b; Xu and Huang, 2001a, 2001b). Xu and Huang (2000a, $2000 \mathrm{~b}$ ) found that exposing roots of creeping bentgrass [Agrostis stolonifera var. palustris (syn. A. palustris)] to high root-zone temperature $\left(35^{\circ} \mathrm{C}\right)$ while maintaining shoots at the optimum air temperature $\left(20^{\circ} \mathrm{C}\right)$ significantly reduced shoot and root growth; lowering root-zone temperature from $35^{\circ} \mathrm{C}$ to $20^{\circ} \mathrm{C}$ at high air temperature $\left(35^{\circ} \mathrm{C}\right)$ had the opposite effects.

High root-zone temperature limits photosynthesis in various species (Al-Khatib and Paulsen, 1984; Foster et al., 1991; Gur et al., 1979; Martin et al., 1989; Ruter and Ingram, 1992; Ziska, 1998), including creeping bentgrass (Xu and Huang, 2000b). High root-zone temperatures interrupt electron transport in photosystem II (Harding et al., 1990), reduce activity of ribulose-1,5bisphosphate carboxylase/oxygenase (Rubisco) (Grover et al., 1986; Ruter and Ingram, 1992), decrease chlorophyll content, and accelerate leaf senescence (Gur et al., 1979). Martin et al. (1989) and Ruter and Ingram (1992) reported a metabolic limitation of photosynthesis which occurred in 'East Palatka' holly (Ilex xattenuata L. 'East Palatka') exposed to supraoptimal rootzone temperature.

Reducing root-zone temperature from the supraoptimal level $\left(35^{\circ} \mathrm{C}\right)$ while exposing shoots to high air temperatures signifi-

Received for publication 23 May 2001. Accepted for publication 29 Apr. 2002. ${ }^{1}$ Postdoctoral research associate.

${ }^{2}$ Associate professor and corresponding author. cantly improved shoot and root growth of creeping bentgrass (Xu and Huang, 2000a, 2001b). Although root-zone temperatures clearly influence growth of cool-season grasses, the physiological basis and in particular the photosynthetic responses to lowering root-zone temperature are not well understood. Therefore, the objectives of this research were to examine photosynthetic responses to reduced root-zone temperatures and investigate whether the effects of reduced root-zone temperature in improving shoot and root growth of creeping bentgrass are related to changes in canopy and leaf photosynthetic capacity. Understanding the physiological factors involved in cool-season grass response to changes in root-zone temperature is important for improving plant heat tolerance using breeding or biotechnology and for developing effective management programs.

\section{Materials and Methods}

Plant materials. Sod pieces of 'L-93' and 'Penncross' creeping bentgrass were collected from 5-year-old field plots in Turf Research Center at Kansas State University, Manhattan, Kan., and transplanted into a medium of 9 sand : 1 fritted clay (Profile Products Ltd., Deerfield, Ill.) (by volume) in clear polyethylene bags $[5 \mathrm{~cm}$ in diameter and $40 \mathrm{~cm}$ in length (volume $=$ $\left.785 \mathrm{~cm}^{3}\right)$ ], with eight holes drilled at the bottom for drainage. The polyethylene bags were placed in opaque polyvinyl chloride tubes of the same diameter and length, which were installed vertically in water baths with the lower open end exposed from the bottom of the water bath for drainage (Xu and Huang, 2001b). These were designed in a way that enabled plant growth in welldrained soil in polyethylene bags, while soil temperature was 
controlled at a constant, predetermined level. Plants were grown in growth chambers set at 14 -h days/11-h nights of $20 / 15^{\circ} \mathrm{C}$ with a 14-h photoperiod during the high temperature portion of the cycle of $400 \mathrm{mmol} \cdot \mathrm{m}^{-2} \cdot \mathrm{s}^{-1}$ (photosynthetically active radiation) for $60 \mathrm{~d}$ before differential air/soil temperature treatments were imposed. Before and during temperature treatments, turf was mowed daily to a 3 to $4 \mathrm{~mm}$ height with an electric hair clipper (Wahl Cliper Co., Sterling Ill.), watered daily until soil moisture reached field capacity (when free drainage ceased from the bottoms of the polyethylene bags), and fertilized weekly with 50 $\mathrm{mL}$ full-strength Hoagland's nutrient solution (Hoagland and Arnon, 1950).

Treatments. Plants were exposed to the following air/soil temperature regimes: 1) optimum air and soil temperatures (20/ $20^{\circ} \mathrm{C}$, control); 2) lowering soil temperature by 3,6 , or $11^{\circ} \mathrm{C}$ from $35^{\circ} \mathrm{C}$ at high air temperature $\left(35 / 32,35 / 29\right.$, and $\left.35 / 24^{\circ} \mathrm{C}\right)$; and 3 ) high air and high soil temperatures $\left(35 / 35^{\circ} \mathrm{C}\right.$, heat stress). Shoots (above-ground portion) were maintained at the ambient temperature $\left(35^{\circ} \mathrm{C}\right)$ of the growth chambers. Soil temperatures were controlled by maintaining the entire root zone $(40-\mathrm{cm}-$ long soil column in a polyethylene bag) in water baths with circulating cool water $\left(18^{\circ} \mathrm{C}\right)$ around the plant containers at variable rates to provide the different soil temperatures (Xu and Huang, 2001b). Water was circulated continuously to maintain a constant and uniform temperature. Water levels were maintained at the top edges of water baths during the experimental period.

Air temperatures at $5 \mathrm{~cm}$ from the canopy, canopy temperature, and soil temperatures at different depths from the soil surface were measured with thermocouples connected to a thermometer. The air and soil temperature profile is reported in $\mathrm{Xu}$ and Huang (2001b). In the control, air temperature was maintained at $\approx 20{ }^{\circ} \mathrm{C}$ and soil temperatures from a 1 to $40 \mathrm{~cm}$ depth ranged from 18 to $20^{\circ} \mathrm{C}$. In the heat stress treatment, air temperature was $35^{\circ} \mathrm{C}$ and soil temperatures from a 1 to $40 \mathrm{~cm}$ depth ranged from 32 to $34{ }^{\circ} \mathrm{C}$. In the reduced soil temperature treatments, air temperature was $35^{\circ} \mathrm{C}$ and soil temperatures along the $40 \mathrm{~cm}$ soil profile ranged from 22 to $26{ }^{\circ} \mathrm{C}$ for the $35 / 24{ }^{\circ} \mathrm{C}$ treatment, 27 to $31^{\circ} \mathrm{C}$ for the $35 / 29^{\circ} \mathrm{C}$ treatment, and 30 to $33{ }^{\circ} \mathrm{C}$ for the $35 / 32{ }^{\circ} \mathrm{C}$ treatment.

Measurements. Canopy net photosynthetic rate $\left(\mathrm{P}_{\text {canopy }}\right)$ and single-leaf net photosynthetic rate $\left(\mathrm{P}_{\text {leaf }}\right)$ were measured from 1000 to $1400 \mathrm{HR}$ on the day before treatment and on day $1,7,14$, and 21 using a portable photosynthesis system (LI-6400; LICOR, Inc., Lincoln, Nebr.). $\mathrm{P}_{\text {canopy }}$ and $\mathrm{P}_{\text {leaf }}$ were also measured at $3 \mathrm{~h}$ and $1 \mathrm{~h}$ after treatments were started. For $\mathrm{P}_{\text {canopy }}$ measurement, the grass canopy was enclosed in a transparent plexiglass chamber fitted to the $\mathrm{CO}_{2}$ analyzer in the photosynthesis system. $\mathrm{P}_{\text {canopy }}$ was expressed as $\mathrm{CO}_{2}$ uptake per unit turf canopy area measured in each treatment plus the soil respiration rate in each plant container. However, soil respiration was minimal in the experiment because the growing medium contained no organic matter and was sterilized before being placed in the containers. $\mathrm{P}_{\text {leaf }}$ measurement followed the procedure described in Xu and Huang (2001a) using excised leaves. Our preliminary test showed that no significant differences occurred in photosynthetic rate measured on intact leaves and excised leaves.

Specifically, a piece of nylon screen was put just beneath the gasket on the lower half of the leaf chamber to hold leaf segments in place. Thirty to 50 leaf segments (6 to $7 \mathrm{~mm}$ in length) were excised from a plant and placed immediately flat onto the screen in the leaf chamber. Then another sheet of screen was put on the top of the leaves in the lower gasket. The $\mathrm{CO}_{2}$ uptake was measured within $30 \mathrm{~s}$ of excision from plants. The photosynthetic photon flux of the leaf chamber was $1000 \mathrm{mmol} \cdot \mathrm{m}^{-2} \cdot \mathrm{s}^{-1}$ provided by a light source installed in the leaf chamber. Leaf chamber temperature was controlled at $35^{\circ} \mathrm{C}$ for measurement of supraoptimal temperature treatments $\left(35 / 35,35 / 32,35 / 29\right.$, and $\left.35 / 24{ }^{\circ} \mathrm{C}\right)$ and at $20^{\circ} \mathrm{C}$ for the optimal temperature treatment $\left(20 / 20{ }^{\circ} \mathrm{C}\right)$. Leaf area was measured after photosynthesis measurements using an image analyzer (Decagon Devices, Inc., Pullman, Wash.).

Leaf photochemical efficiency (Fv/Fm) was determined using a chlorophyll fluorescence induction monitor (Dynamax, Houston, Texas) on day $0,7,14$, and 21 . Fv/Fm is a ratio of the variable fluorescence to the maximal fluorescence of chlorophyll. This ratio is proportional to the quantum yield of photochemistry and shows a high degree of correlation with quantum yield of net photosynthesis (Ogren, 1991). Chlorophyll content was determined on day $0,6,13$, and 20 using the method of Hiscox and Israelstam (1979). Chlorophyll was extracted by soaking leaves in dimethyl sulfoxide for $48 \mathrm{~h}$. Absorbance of extracts was measured at 663 and $645 \mathrm{~nm}$ with a Genesys 2 spectrophotometer (Spectronic Instruments, Inc., Rochester, N.Y.).

Rubisco activity in leaves was determined on day $0,1,7,14$, and 21 using the method of Laurie and Steward (1993). Leaf tissue $(0.5$ to $1 \mathrm{~g})$ was ground in a mortar with $10 \mathrm{~mL}\left(0\right.$ to $\left.4^{\circ} \mathrm{C}\right)$ buffer solution containing $100 \mathrm{~mm}$ Tris- $\mathrm{HCl}$ (pH 7.8), $10 \mathrm{~mm}$ $\mathrm{M}_{\mathrm{g}} \mathrm{Cl}_{2}, 1$ mM ethylenediamine tetra-acetic acid(EDTA), $10 \mathrm{~mm} 2-$ mercaptoethanol, and $12.5 \%$ (v/v) glycerol, and then centrifuged

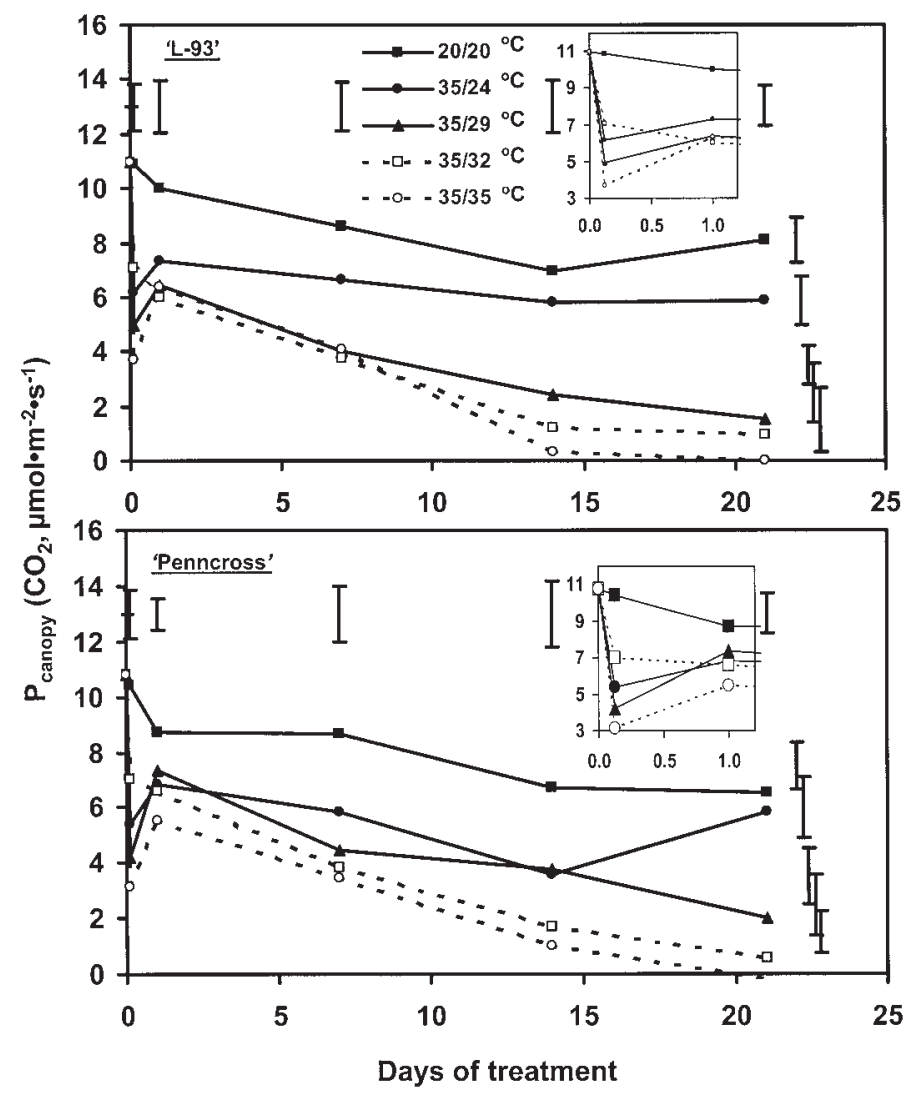

Fig. 1. Responses of canopy net photosynthetic rate $\left(\mathrm{P}_{\text {canopy }}\right)$ to reduced root-zone temperature of 'L-93' and 'Penncross' creeping bentgrasses. Vertical bars at the top of the graphs indicate Tukey's studentized range test values $(P=0.05)$ for treatment comparisons within a given time of treatment. Vertical bars on the right indicate Tukey's studentized range test values $(P=0.05)$ for comparisons over time within a given treatment. Inner figures indicate canopy photosynthetic rate at 0,3 , and $24 \mathrm{~h}$ of treatment. 
at 39,000 $g_{n}$ for $30 \mathrm{~min}$. The supernatants were decanted into test tubes that were stored in ice until assay. Rubisco activity was measured following the incorporation of ${ }^{14} \mathrm{C}$ into acid-stable product using $\mathrm{NaH}^{14} \mathrm{CO}_{3}$. A $0.5 \mathrm{~mL}$ of $200 \mathrm{~mm}$ Hepes solution containing $20 \mathrm{mM} \mathrm{M}_{\mathrm{g}} \mathrm{Cl}_{2}, 0.2 \mathrm{~mm} \mathrm{Na} \mathrm{NDT}_{2}$ A, $0.2 \mathrm{~mL}$ of $200 \mathrm{~mm}$ $\mathrm{NaH}^{14} \mathrm{CO}_{3}\left(5 \mathrm{~Bq} \cdot \mathrm{mL}^{-1}\right)$, and $0.1 \mathrm{~mL}$ supernatant was mixed in liquid scintillation vials. The vials were sealed and incubated at $25^{\circ} \mathrm{C}$ for $10 \mathrm{~min}$. The reaction was started by adding $0.2 \mathrm{~mL}$ of $3 \mathrm{~mm}$ ribulose biosphosphate solution to each vial. The vials were sealed and incubated at $25^{\circ} \mathrm{C}$ for 5 min with continuous shaking. The reaction was stopped by adding $0.2 \mathrm{~mL}$ of $2 \mathrm{~N} \mathrm{HCl}$ to each vial, and all vials were left open in a hood for $12 \mathrm{~h}$. Then $4 \mathrm{~mL}$ of scintillation cocktail was added to each vial. Radioactivity of the solution was measured with a scintillation counter (R.J. Harvey Instrument Corp., Hillsdale, N.J.) and used to calculate Rubisco activity expressed as $\mu \mathrm{mol} \mathrm{NaHCO}_{3}$ fixed to acid-stable compound per unit leaf fresh weight (FW) per hour.

EXPERIMENT DESIGN AND STATISTICAL ANALYSIS. Temperatures and cultivars were arranged in a randomized split-plot design with repeated measures (Snedecor and Cochran, 1989). Temperature was treated as the main plot and cultivar as the subplot. Measurements were made at various times to study time response to temperature treatments. Cultivars were arranged randomly in each temperature regime in each chamber. All measurements were taken on two tubes (two subsamples) sampled randomly in each treatment at various times of treatments (last harvest on day
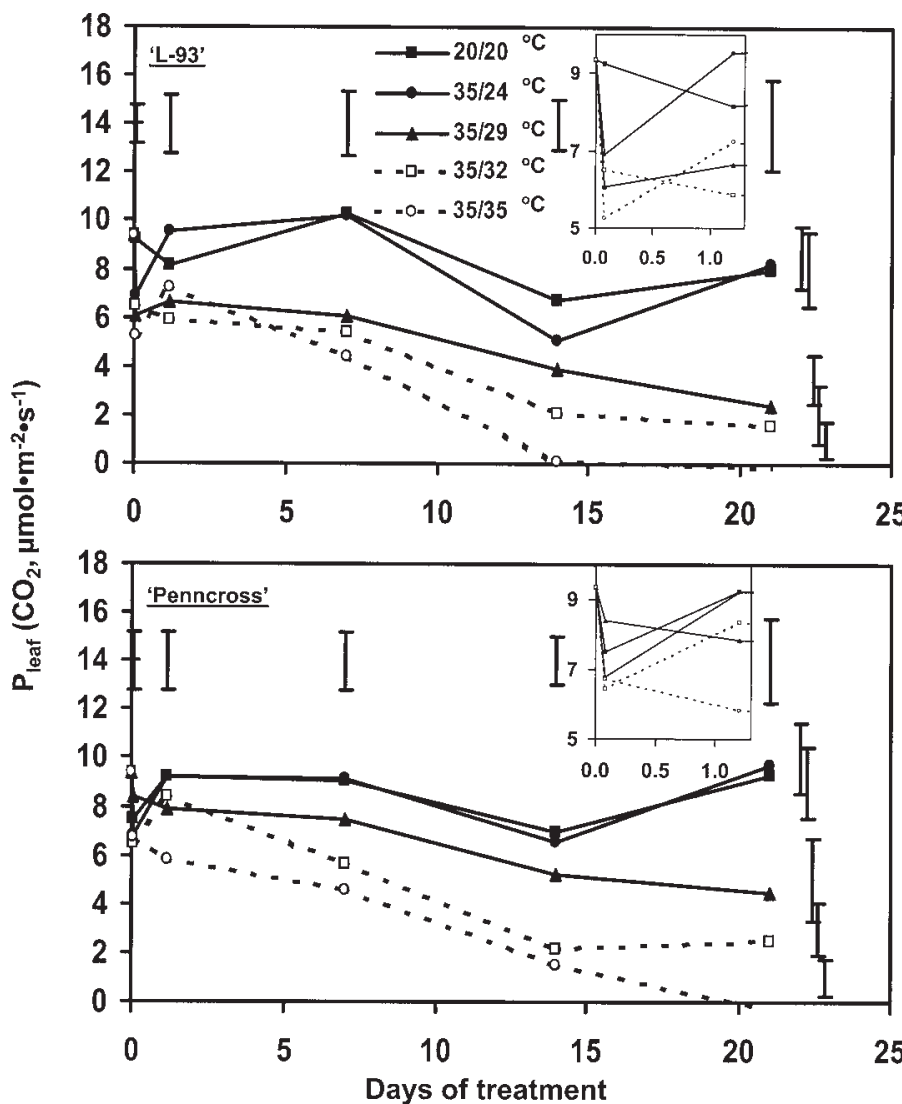

Fig. 2. Responses of single-leaf net photosynthetic rate $\left(\mathrm{P}_{\text {leaf }}\right)$ to reduced root-zone temperature of 'L-93' and 'Penncross' creeping bentgrasses. Vertical bars at the top of the graphs indicate Tukey's studentized range test values $(P=0.05)$ for treatment comparisons within a given time of treatment. Vertical bars on the right indicate Tukey's studentized range test values $(P=0.05)$ for comparisons over time within a given treatment. Inner figures indicate single-leaf photosynthetic rate at 0,1 , or $30 \mathrm{~h}$ of treatment.
21 of treatment). The experiment was conducted three times in different growth chambers and water baths as three replications. Growth chambers and water baths were rotated among temperature treatments to minimize equipmental error for each run. Effects of temperature, cultivar, time of treatment, and their interactions were determined using a single three-way analysis of variance according to the general linear model procedure of the Statistical Analysis System (SAS Institute Inc., Cary, N.C.). Each treatment mean was the average of three replicates that were derived from the average of two subsamples. Treatments means were separated by Tukey's studentized range test at $P<0.05$.

\section{Results}

The main effects of temperature treatment and date were significant at $P<0.05$ for all parameters examined. The main effects of cultivar were not significant except for $\mathrm{P}_{\text {canopy }}$. The interaction between temperature treatment and date was significant for all parameters.

$\mathrm{P}_{\text {canopy }}$ (Fig. 1) and $\mathrm{P}_{\text {leaf }}$ (Fig. 2) were reduced to below the control level $\left(20 / 20^{\circ} \mathrm{C}\right)$ by the first measurement (at $3 \mathrm{~h}$ and $1 \mathrm{~h}$ after induction of treatment, respectively), after ' $\mathrm{L}-93$ ' and 'Penncross' were exposed to $35 / 35^{\circ} \mathrm{C}$ and remained lower than the control level $\left(20 / 20^{\circ} \mathrm{C}\right)$ during the rest of the experimental period. $\mathrm{P}_{\text {canopy }}$ and $\mathrm{P}_{\text {leaf }}$ of both cultivars were increased to above the level at $35 / 35{ }^{\circ} \mathrm{C}$ beginning on day 7 for $\mathrm{P}_{\text {canopy }}$ and on day 1 for $\mathrm{P}_{\text {leaf }}$ when root-zone temperature was reduced to $24{ }^{\circ} \mathrm{C}$. The
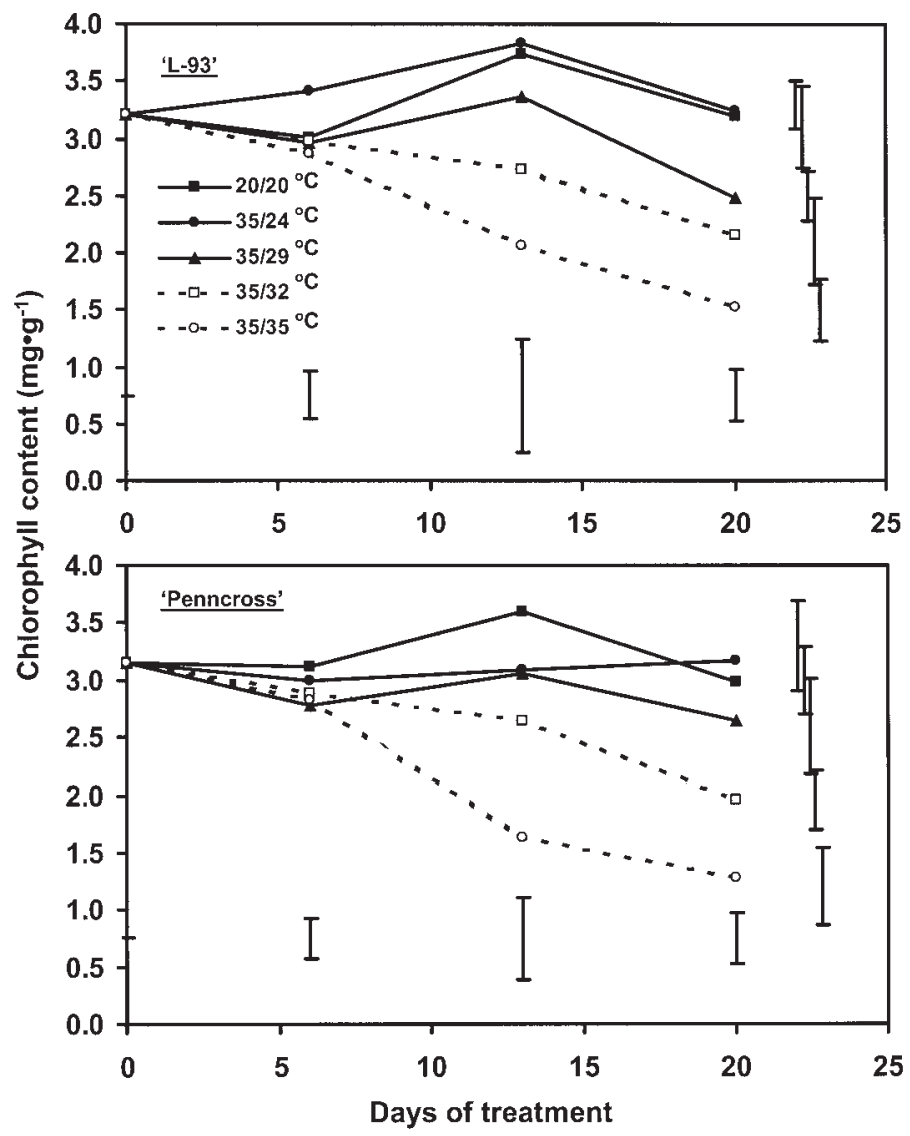

Fig. 3. Responses of leaf chlorophyll content to reduced root-zone temperature of 'L-93' and 'Penncross' creeping bentgrasses. Vertical bars on the top indicate Tukey's Studentized range test values $(P=0.05)$ for treatment comparisons within a given time of treatment. Vertical bars on the right indicate Tukey's studentized range test values $(P=0.05)$ for comparisons over time within a given treatment. 
improvements were observed on day 14 for $\mathrm{P}_{\text {canopy }}$ and day 7 for $\mathrm{P}_{\text {leaf }}$ when root-zone temperature was lowered to $29{ }^{\circ} \mathrm{C}$. $\mathrm{P}_{\text {canopy }}$ did not increase to the control level during most of the experiment period, but $\mathrm{P}_{\text {leaf }}$ of plants of both cultivars in the $35 / 24^{\circ} \mathrm{C}$ treatment returned to the control level throughout the entire experiment. Reducing rootzone temperature from 35 to $32^{\circ} \mathrm{C}$ was not effective in improving $\mathrm{P}_{\text {canopy }}$ or $\mathrm{P}_{\text {leaf }}$ in either cultivar.

Leaf chlorophyll content at $35 / 35^{\circ} \mathrm{C}$ was lower than that at 20 / $20^{\circ} \mathrm{C}$ (control) by day 7 for 'Penncross' and day 14 for 'L-93' (Fig. $3)$. When root-zone temperatures were reduced from $35^{\circ} \mathrm{C}$ to 32,29 , and $24{ }^{\circ} \mathrm{C}$, chlorophyll content was higher than that at $35 / 35{ }^{\circ} \mathrm{C}$ on day 14 and 21 of treatment for both cultivars. It remained at the control level for ' $\mathrm{L}-93$ ' at $35 / 24^{\circ} \mathrm{C}$ and for 'Penncross' at 35/29 and $35 / 24^{\circ} \mathrm{C}$ during the entire treatment period.

Supraoptimal air and root-zone temperatures reduced Fv/Fm beginning on day 7 of treatment for both cultivars (Fig. 4). Reducing root-zone temperature from 35 to $24{ }^{\circ} \mathrm{C}$ resulted in a $\mathrm{Fv} / \mathrm{Fm}$ level comparable to that of the control during the entire treatment period for 'L-93' and on day 7 and 21 for 'Penncross'. The reduction in root-zone temperature by 3 or $6^{\circ} \mathrm{C}$ resulted in a $\mathrm{Fv} / \mathrm{Fm}$ on day 7 of treatment comparable to the control for both cultivars.

Rubisco activity was reduced to below the control level beginning on day 7 of $35 / 35^{\circ} \mathrm{C}$ for both cultivars (Fig. 5). Reduced rootzone temperature from $35^{\circ} \mathrm{C}$ to 29 and $24{ }^{\circ} \mathrm{C}$ resulted in greater Rubisco activity compared with $35 / 35^{\circ} \mathrm{C}$ beginning on day 7 for ' $\mathrm{L}$ 93' and day 14 for 'Penncross'. Rubisco activity at $35 / 24{ }^{\circ} \mathrm{C}$ remained at the same level as that at $20 / 20^{\circ} \mathrm{C}$ in both cultivars. Root-

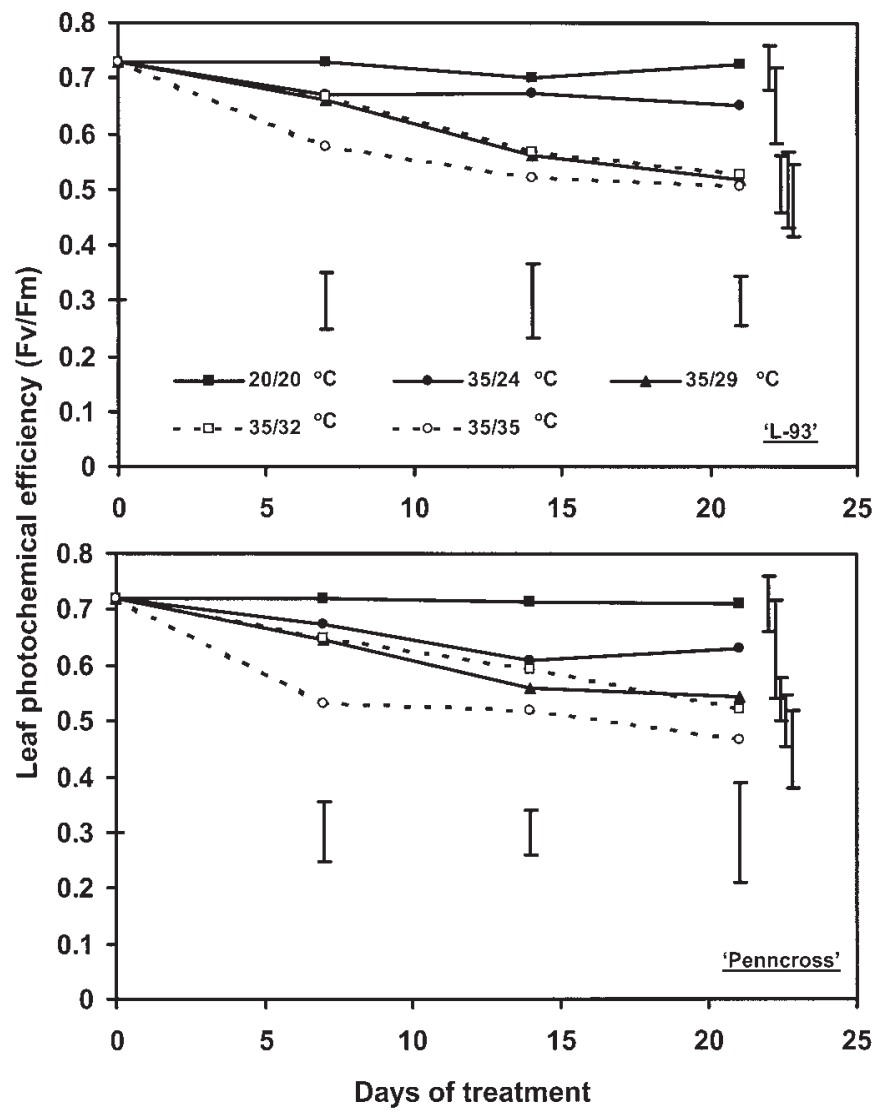

Fig. 4. Responses of $\mathrm{Fv} / \mathrm{Fm}$ to reduced root-zone temperature of 'L-93' and 'Penncross' creeping bentgrasses. Vertical bars at the top of the graphs indicate Tukey's studentized range test values $(P=0.05)$ for treatment comparisons within a given time of treatment. Vertical bars on the right indicate Tukey's studentized range test values $(P=0.05)$ for comparisons over time within a given treatment. zone temperature reduction from $35{ }^{\circ} \mathrm{C}$ to $32{ }^{\circ} \mathrm{C}$ had no effect on Rubisco activity.

\section{Discussion}

Both $\mathrm{P}_{\text {canopy }}$ and $\mathrm{P}_{\text {leaf }}$ were reduced within a day after grasses were exposed to high air and root-zone temperatures and remained lower than the control during the entire experimental period in both cultivars, suggesting that both canopy and single-leaf photosynthetic rate were sensitive to high temperatures. Reductions in leaf chlorophyll content, Fv/Fm, and Rubisco activity occurred beginning day 7 of exposure to high air and root-zone temperatures, indicating that heat stress caused a loss of chlorophyll and damage to photosynthetic electron transport systems and Rubisco activity. Photosynthetic inhibition by increasing root-zone temperature has been reported in other species (Foster et al., 1991; Ruter and Ingram, 1992).

A $3{ }^{\circ} \mathrm{C}$ reduction in root-zone temperature was not effective in improving $\mathrm{P}_{\text {leaf }}$ or $\mathrm{P}_{\text {canopy }}$ for either cultivar. However, our previous study reported that $3^{\circ} \mathrm{C}$ reduction in soil temperature increased turf quality and root growth for 'L-93' and 'Penncross' (Xu and Huang, 2001b). The improved turf quality and root growth with this level of soil temperature reduction apparently was not related to changes in $\mathrm{P}_{\text {leaf }}$ or $\mathrm{P}_{\text {canopy }}$, and could be attributed to other physiological factors. Reducing root-zone temperature by 6 or $11^{\circ} \mathrm{C}$ (from $35^{\circ} \mathrm{C}$ to 24 or $29{ }^{\circ} \mathrm{C}$ ) while maintaining air temperature at $35{ }^{\circ} \mathrm{C}$ significantly improved $\mathrm{P}_{\text {leaf }}$ and $\mathrm{P}_{\text {canopy }}$ in both cultivars. These results suggest that
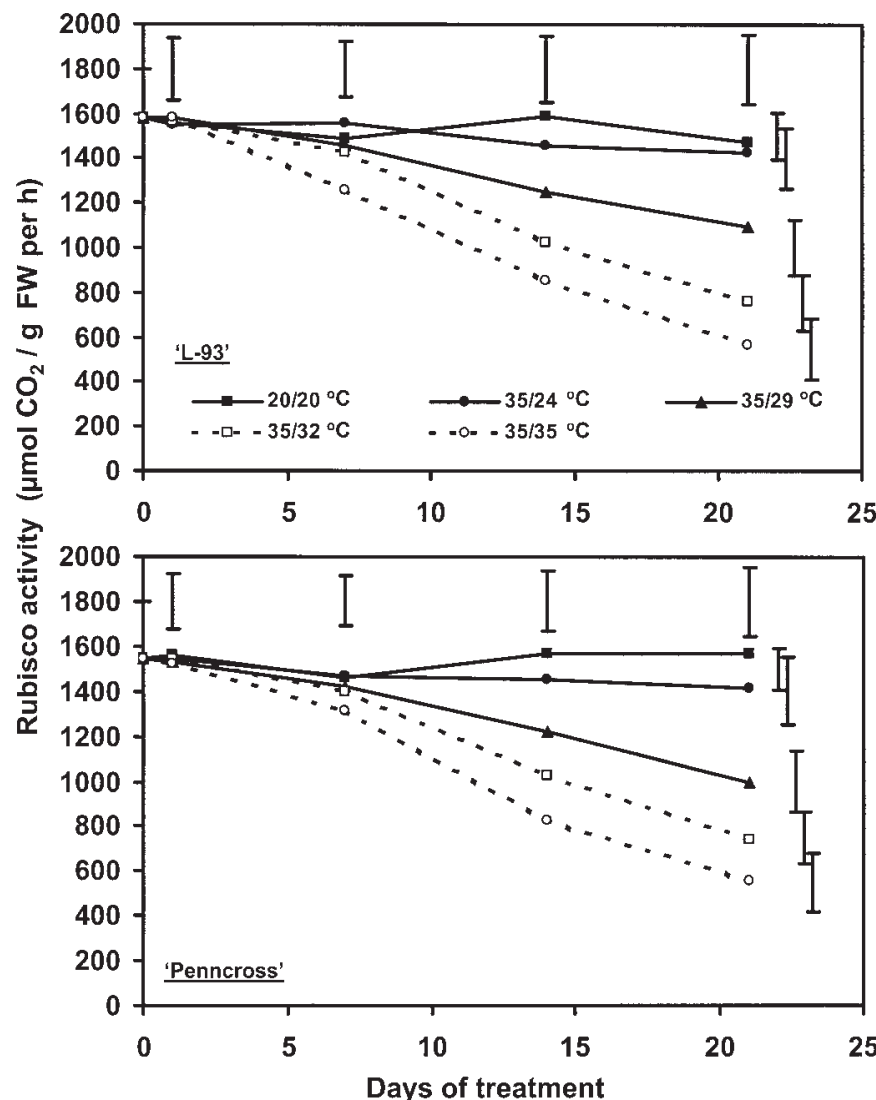

Fig. 5. Responses of leaf Rubisco activity to reducing root-zone temperature of ' $\mathrm{L}$ 93' and 'Penncross' creeping bentgrasses. Vertical bars at the top of the graphs indicate Tukey's studentized range test values $(P=0.05)$ for treatment comparisons within a given time of treatment. Vertical bars on the right indicate Tukey's studentized range test values $(P=0.05)$ for comparisons over time within a given treatment. 
any cultural practices such as syringing, fan, and sub-air cooling system that could reduce root-zone temperature by $6{ }^{\circ} \mathrm{C}$ or more would help creeping bentgrass maintain high photosynthetic capacity, even when air temperature is at the supraoptimal level. The increases in both $\mathrm{P}_{\text {leaf }}$ and $\mathrm{P}_{\text {canopy }}$ with lowered root-zone temperature at high air temperature could contribute to improved turf quality, leaf growth rate, and root growth as reported by $\mathrm{Xu}$ and Huang (2000a, 2000b). To prevent or alleviate summer bentgrass decline, soil temperature reduction should be considered as an important approach to enhance photosynthetic capacity when air temperature is supraoptimal. Effective and easy methods need to be developed to reduce soil temperature on golf greens. Such increases in photosynthesis may be mediated by enhanced root physiological activities with low root-zone temperature, including cytokinin synthesis (Gur et al., 1979; Liu et al., 2001; Udomprasert et al., 1995) and water and mineral nutrient uptake (Graves et al., 1991; Hood and Mills, 1994; Huang and Xu, 2000; Klock et al., 1997; Yeager et al., 1991). Liu et al. (2001) reported that addition of zeatin riboside to the root zone in creeping bentgrass improved photosynthetic rate when soil temperature was supraoptimal.

Improvement in $\mathrm{P}_{\text {leaf }}$ in the present investigation occurred earlier and was more pronounced than that for $\mathrm{P}_{\text {canopy }}$ as root-zone temperature was reduced from 35 to 24 or $29{ }^{\circ} \mathrm{C}$; moreover, an $11{ }^{\circ} \mathrm{C}$ reduction in root-zone temperature caused full recovery for $\mathrm{P}_{\text {leaf }}$, but

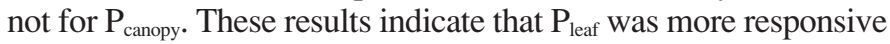
to the reduction in root-zone temperature. In general, three major factors control the photosynthetic rate of the whole canopy: $\mathrm{P}_{\text {leaf }}$, leaf area, and geometry of the leaf canopy (Woledge and Leafe, 1976). $\mathrm{Xu}$ and Huang (2001b) reported that similar to $\mathrm{P}_{\text {canopy }}$, tiller density and leaf dry weight increased with root-zone temperature reduction from $35^{\circ} \mathrm{C}$ to $24^{\circ} \mathrm{C}$, but never reached the control $\left(20 / 20^{\circ} \mathrm{C}\right)$ level. Therefore, the slow increases in $\mathrm{P}_{\text {canopy }}$ may be controlled mainly by the responses of leaf morphological factors. The increase in $\mathrm{P}_{\text {leaf }}$ Was accompanied by increases in leaf chlorophyll content, Fv/Fm, and Rubisco activity when root-zone temperature was reduced by $6^{\circ} \mathrm{C}$. This suggests that enhancement of single-leaf photosynthetic rates could be related to reduction of metabolic limitation when root-zone temperature was reduced slightly.

In summary, supraoptimal air and root-zone temperatures reduced both canopy and single-leaf photosynthetic capacity of creeping bentgrass by damaging the photosynthetic apparatus and Rubisco activity after a prolonged period of stress. A $3^{\circ} \mathrm{C}$ reduction in soil temperature was not effective in improving photosynthetic capacity. A root-zone temperature reduction by 6 or $11^{\circ} \mathrm{C}$ from 35 ${ }^{\circ} \mathrm{C}$ under high air temperature conditions was effective in improving photosynthetic capacity, as manifested by improving canopy and single-leaf photosynthetic rate, leaf chlorophyll content, photochemical efficiency, and enzyme metabolic activity. These results suggest that heat tolerance of creeping bentgrass could be improved by selecting for plants with high photosynthetic activities in a breeding program. Any management practices that reduce soil temperature by $3^{\circ} \mathrm{C}$ or higher could help maintain turf growth under high air temperature conditions.

\section{Literature Cited}

Al-Khatib, K. and G.M. Paulsen. 1984. Mode of high temperature injury to wheat during grain development. Physiol. Plant. 61:363-368.

Foster, W.J., D.L. Ingram, and T.A. Nell. 1991. Photosynthesis and root respiration in Ilex crenata 'Rotundifolia' at supraoptimal root-zone temperatures. HortScience 26:535-537.

Graves, W.R., R.Y. Joly, and M.N. Dana. 1991. Water use and growth of honey locust and tree of heaven at high root-zone temperature. HortScience 26:1309-1312.
Grover, A., S.C. Sabat, and P. Mohanty. 1986. Effect of temperature on photosynthetic activities of senescing detached wheat leaves. Plant Cell Physiol. 27:117-126.

Gur, A., J. Hepner, and Y. Shulman. 1979. The influence of root temperature on apple trees. IV. The effect on the mineral nutrition of the tree. J. Hort. Sci. 54:313-321.

Harding, S.A., J.A. Guikema, and G.M. Paulsen. 1990. Photosynthetic decline from high temperature stress during maturation of wheat. I. Interaction with senescence processes. Plant Physiol. 92:648-653.

Hiscox, J.H. and G.F. Israelstam. 1979. A method for the extraction of chlorophyll from leaf tissue without maceration. Can. J. Bot. 57:13321334.

Hoagland, D.R. and D.I. Arnon. 1950. The water-culture method for growing plants without soil. Calif. Agr. Expt. Sta. Circ. 347.

Hood, T.M. and H.A. Mills. 1994. Root-zone temperature affects nutrient uptake and growth of snapdragon. J. Plant Nutr. 17:279-291.

Huang, B. and Q. Xu. 2000. Root growth and nutrient element status of creeping bentgrass cultivars differing in heat tolerance as influenced by supraoptimal shoot and root temperatures. J. Plant Nutr. 23:979-990.

Klock, K.A., H.G. Taber, and W.R. Graves. 1997. Root respiration and phosphorus nutrition of tomato plants grown at a $36{ }^{\circ} \mathrm{C}$ root-zone temperature. J. Amer. Soc. Hort. Sci. 122:175-178.

Kuryanagi, T. and G.M. Paulsen. 1988. Mediation of high temperature injury by roots and shoots during reproductive growth of wheat. Plant Cell Environ. 11:517-523.

Laurie, M. and G.R. Steward. 1993. Effects of nitrogen supply and high temperature on the growth and physiology of the chickpea. Plant Cell Environ. 16:609-621.

Liu, X., B. Huang, and G. Banowetz. 2001. Cytokinin effects on creeping bentgrass responses to heat stress. I. Shoot and root growth. Crop Sci. 42:457-465.

Martin, C.A., D.L. Ingram, and T.A. Nell. 1989. Supraoptimal root-zone temperature alters growth and photosynthesis of holly and elm. J. Arboricult. 15:272-276.

Ogren, E. 1991. Prediction of photoinhibition of photosynthesis from measurements of fluorescence quenching components. Planta 184:538544.

Paulsen, G.M. 1994. High temperature responses of crop plants, p. 365389. In: K.J. Booth, T. Sinclair, and G.M. Paulsen (eds.). Physiology and determination of crop yield. Amer. Soc. Agron., Crop Sci. Soc. Amer., and Soil Sci. Soc. Amer., Madison, Wis.

Ruter, J.M. and D.L. Ingram. 1992. High root-zone temperatures influence RuBisCO activity and pigment accumulation in leaves of 'Rotundifolia' holly. J. Amer. Soc. Hort. Sci. 117:154-157.

Snedecor, G.W. and W.G. Cochran. 1989. Statistical methods. $8^{\text {th }}$ ed. Iowa State Univ. Press. Ames.

Udomprasert, N., P.H. Li, D.W. Davis, and A.H. Markhart. 1995. Effects of root temperature on leaf gas exchange and growth at high air temperature in Phaseolus acutifolius and Phaseolus vulgaris. Crop Sci. 35:490495.

Woledge, J. and E.L. Leafe. 1976. Single leaf and canopy photosynthesis in a ryegrass sward. Ann. Bot. 40:773-783.

$\mathrm{Xu}, \mathrm{Q}$. and B. Huang. 2000a. Growth and physiological responses of creeping bentgrass to changes in air and soil temperatures. Crop Sci. 40:1361-1368

Xu, Q. and B. Huang. 2000b. Effects of differential air and soil temperature on carbohydrate metabolism in creeping bentgrass. Crop Sci. 40:13681374.

Xu, Q. and B. Huang. 2001a. Morphological and physiological characteristics associated with heat tolerance in creeping bentgrass. Crop Sci. 41:127-133.

Xu, Q. and B. Huang. 2001b. Lowering soil temperature improves creeping bentgrass growth under heat stress. Crop Sci. 41:1878-1883.

Yeager, T.H., R.H. Harrison, and D.L. Ingram. 1991. 'Rotundifolia' holly growth and nitrogen accumulation influenced by supraoptimal root-zone temperatures. HortScience 26:1387-1388.

Ziska, L.H. 1998. The influence of root zone temperature on photosynthetic acclimation to elevated carbon dioxide concentrations. Ann. Bot. 81:717721. 